\title{
Embargo Ekonomi sebagai Strategi Konfrontasi Uni Eropa terhadap Rusia pada Masa Konflik Ukraina 2013-2015
}

\author{
Ummu Ro’iyatu Nahdliyati Millati Hanifah* \\ urnm.hany@gmail.com
}

\begin{abstract}
Abstraksi
Posisi Ukraina yang strategis bagi Rusia maupun Uni Eropa seringkali menjadikannya sebagai medan konflik antara Rusia dan Uni Eropa. Seperti yang terjadi pada tahun 2013-2015, konflik domestik yang diawali oleh keluarnya Ukraina dari Perjanjian Asosiasi Eropa menjadi medan konflik antara Rusia dan Uni Eropa. Rusia yang merupakan negara pewaris Soviet merasa perlu untuk melindungi etnis Rusia yang berada di Ukraina menuntut Rusia untuk melakukan campur tangan dalam konflik domestik tersebut. Sedangkan Uni Eropa yang merasa kepentingan politiknya diganggu oleh Rusia pada akhirnya melakukan embargo ekonomi terhadap Rusia atas campur tangannya tersebut, sementara Uni Eropa memiliki ketergantungan terhadap Rusia dalam hal energi. Dalam penelitian ini akan dibahas mengenai embargo ekonomi yang diberikan oleh Uni Eropa terhadap Rusia serta latar belakang embargo tersebut dengan menggunakan teori foreign policy strategy dan konsep energy security. Penelitian ini menggunakan metode penelitian eksplanatif dengan menggunakan data kualitatif yang bersumber dari studi kepustakaan. Kebijakan embargo ekonomi yang dilakukan oleh Uni Eropa tersebut merupakan strategi konfrontasi Uni Eropa terhadap Rusia yang di dasari oleh dua hal, yaitu kapabilitas Uni Eropa yang dirasa lebih tinggi daripada Rusia serta posisi Rusia yang dianggap sebagai ancaman oleh Uni Eropa.
\end{abstract}

Kata Kunci: Perjanjian Asosiasi Eropa, embargo ekonomi, strategi konfrontasi, konflik. Ukraina.

\begin{abstract}
Strategical position of Ukraine for Russia as well as European Union often make it be conflict area between Russia and European Union. As happened to the years 2013-2015, domestic conflict that begins by the discharge of Ukraine of the European Association Agreement became the conflict zone between Russia and the European Union. Russia that legacy of Soviet Union felt it necessary to protect Russians ethnic who were in Ukraine make Russia demands to intervene in the domestic conflict. Whereas the European Union felt harassed by the political interests of Russia finally of give economic embargo to the Russian on interference in the domestic conflict, while European Union dependence on Russian energy. In this research will be discussed about the economic embargo by the European Union on Russia and the background of the embargo by using the theory of foreign policy strategy and concept of energy security. This research use explainative methode with qualitative data that sourced by library research. The economic embargo is European Union confrontation strategy towards Russia that based on two reasons, capability the European Union is considered higher than Russia and Russia's position is seen as a threat by the European Union.
\end{abstract}

Key Words: European Association Agreement, economic embargo, confrontation strategy, Ukraina conflict.

\footnotetext{
* Korespondensi: Centre of Social Studies Community, Perum Karangploso View, Malang. Telp: 081233593009, Email: cssc.indonesia@gmail.com
} 


\section{Latar Belakang}

Adanya krisis domestik di Ukraina bermula ketika presiden Ukraina, Viktor Yanukovych mengumumkan bahwa Ukraina mundur dari Perjanjian Asosiasi Uni Eropa (UE) pada bulan November 2013. Hal ini memicu munculnya protes besarbesaran oleh para mahasiswa di Kiev yang menyebabkan diturunkannya Yanukovych dari jabatannya sebagai presiden pada Februari 2014 (BBC, 2014.c). Pasca jatuhnya presiden Ukraina, kekuasaan Ukraina terbagi menjadi dua pengaruh yaitu berasal dari Barat (Uni Eropa dan Amerika Serikat) serta dari Rusia.

Perdana Menteri Crimea, Sergei Aksenov meminta bantuan kepada Rusia untuk menyelesaikan konflik tersebut. Hal ini dikarenakan Sergei Aksenov lebih condong terhadap pengaruh dari Rusia daripada pengaruh Barat (Kompas, Kamis 20 Maret 2014:9). Atas Permintaan tersebut, Rusia mengirimkan tentaranya untuk menduduki Crimea (Adam dan Paramitha, 2014). Selain atas permintaan PM Ukraina, Rusia juga memiliki kepentingan lain dalam intervensinya di Ukraina. Ukraina secara startegis memiliki posisi yang penting bagi Rusia (jakartagreater.com, 2014). Selain itu, Rusia juga mengusung kepentingan etnis (Anto Sanjoyo, 2014), geopolitik (Ahmad Yoni Setiawan, 2014: bab III), serta kepentingan menjaga pengaruh di kawasan Eropa Timur dalam intervensinya di Ukraina tersebut (Lailatur Riva, 2012).

Intervensi yang dilakukan Rusia ini melahirkan ketegangan baru antara Rusia dengan Ukraina. Ketegangan antara dua negara tersebut mencapai puncaknya ketika Ukraina menyatakan diri ingin bergabung dengan UE (voaindonesia.com, 2015). Sedangkan bagi Rusia adanya perluasan UE hingga ke Eropa Timur (termasuk di dalamnya adalah perluasan hingga Ukraina) adalah suatu bentuk penghinaan terhadap kekuatan Rusia (Dinna Wisnu, 2014). Sehingga, untuk menjaga pengaruhnya di Eropa Timur tetap eksis maka Rusia harus melakukan intervensi dalam konflik Ukraina. Adanya intervensi Rusia tersebut akhirnya membuat UE untuk mengambil kebijakan memberikan embargo ekonomi kepada Rusia sebagai bentuk perlindungan terhadap Ukraina.

Adanya kebijakan embargo ekonomi tersebut membuat banyak negara UE mengalami kekhawatiran akan kekurangan energi. Pasalnya negara-negara EU mengalami ketergantungan yang besar terhadap suplai energi Rusia. Sebagai negara yang bergantung pada pasokan energi dari Rusia, UE lazimnya melakukan negosiasi 
agar tidak terjadi penghentian pasokan gas. Akan tetapi, respon yang diberikan UE justru sebaliknya, yaitu memberikan embargo ekonomi kepada Rusia. Sehingga menjadi menarik untuk dikaji dan diteliti mengenai alasan mengapa UE memberikan respon embargo ekonomi terhadap Rusia atas intervensi tersebut, mengingat besarnya ketergantungan energi negara-negara UE terhadap Rusia.

Untuk membatasi peneliti agar tidak melebar luas, peneliti memfokuskan penelitian ini pada alasan pemberian sanksi embargo oleh Uni Eropa terhadap Rusia atas intervensi politik pada konflik domestik di Ukraina dengan menggunakan konsep energy security serta teori foreign policy strategy. Adapun fokus penelitian pada konflik dalam rentang waktu Februari 2014 sampai dengan Desember 2015, yaitu sejak Presiden Ukraina diturunkan dari jabatannya sampai saat embargo ekonomi yang diberikan UE terhadap Rusia memberikan efek terhadap perekonomian Rusia.

\section{Teori Foreign Policy Strategy}

Menurut Lovell, interaksi antar negara ditentukan oleh dua variabel, yaitu posisi negara lain terhadap negara sendiri serta estimasi kapabilitas negara sendiri dalam berbagai sektor kekuatan (John P. Lovell, 1970:99). Kedua variabel tersebut akan menentukan strategi yang akan dilakukan oleh suatu negara terhadap negara lain. Strategi tersebut digambarkan dalam pola sebagai berikut:

\section{Own Capabilities Superrior}

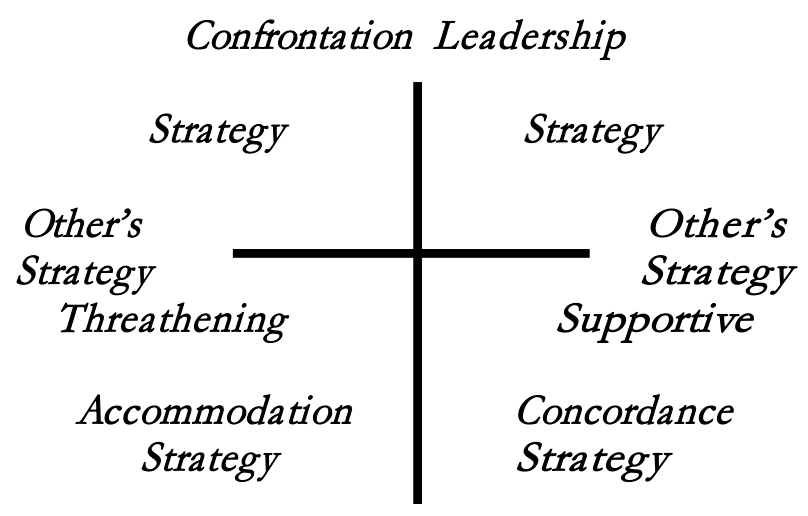

Own Capabilities Inferior 
Leadership Strategy merupakan suatu strategi di mana suatu negara menganggap kapabilitas negaranya lebih tinggi dari negara lain serta menganggap negara lain mendukung tujuan nasional negaranya. Concordance Strategy merupakan suatu strategi yang diterapkan suatu negara di mana negara tersebut merasa kapabilitas negaranya lebih rendah dari negara lain dan menganggap negara lain sebagai pendukung dari tujuan nasional negaranya. Accommodation Strategy merupakan suatu strategi yang diterapkan suatu negara di mana negara tersebut menganggap kapabilitas negaranya lebih rendah daripada kapabilitas negara lain, serta memiliki anggapan bahwa negara lain tersebut menjadi ancaman bagi negaranya. Sedangkan Confrontation Strategy merupakan strategi yang diterapkan oleh suatu negara di mana negara tersebut memiliki kapabilitas lebih tinggi daripada negara lain serta negara lain merupakan ancaman bagi tujuan nasional negaranya.

Teori strategi ini digunakan untuk menjelaskan perilaku UE terhadap Rusia di mana dalam hal ini UE dianalogikan sebagai suatu negara. Hal ini dikarenakan struktur UE yang menyerupai negara dan dapat dianalogikan sebagai suatu negara dalam proses pengambilan kebijakannya. Strategi yang diterapkan oleh UE dalam bentuk embargo ekonomi merupakan bentuk penerapan strategi konfrontasi dalam teori ini di mana UE menganggap kapabilitasnya lebih besar daripada Rusia serta menganggap Rusia ancaman baginya. Teori ini akan mampu menjelaskan bagaimana kapabilitas UE serta posisi Rusia dalam pandangan UE, sehingga UE mengambil keputusan untuk memberikan embargo ekonomi Rusia.

\section{Konsep Energy Security}

International Energy Agency (IEA) mendefinisikan keamanan energi sebagai ketersediaan sumber energi yang tidak terputus dengan harga yang terjangkau. Pasokan energi tersebut dapat bersumber dari cadangan sumber energi dalam negeri ataupun mengimpor sumber energi dari negara lain (Azmi dan Syarif, 2014:1-2). Dengan adanya kebutuhan yang pokok akan energi tersebut maka timbullah saling ketergantungan antar negara-negara di dunia dalam hal ekspor dan impor energi.

Dalam penelitian ini konsep energy security digunakan untuk menjelaskan keadaan saling ketergantungan energi di Eropa dengan Rusia yang ketika terjadi konflik maka keamanan sektor energi ini akan terganggu. Maka yang akan terjadi jika muncul 
konflik antara UE dengan Rusia adalah berkurangnya pasokan gas yang mengalir ke UE. Hal tersebut menimbulkan masalah untuk UE yaitu terancamnya keamanan pasokan energi mereka. Konsep energy security ini akan menjelaskan bagaimana efek berkurangnya pasokan gas ke UE terhadap perilaku UE ke Rusia. Bagaimana kebijakannya dalam menangani masalah energi dan reaksi Rusia atas perilaku UE akan dapat dijelaskan pula melalui konsep ini.

\section{Metode Penelitian}

Dalam penelitian ini, penulis menggunakan metode penelitian library research di mana data yang digunakan merupakan data sekunder yang diperoleh bersumber dari buku-buku, majalah, koran, sumber yang berasal dari internet serta sumber data lainnya. Menurut Matthew B. Miles dan A. Michael Huberman langkahlangkah penelitian kualitatif meliputi; 1) Membangun kerangka konseptual, 2) Merumuskan permasalahan penelitian, 3) Pemilihan sampel dan pembatasan penelitian, 4) Instrumentasi, 5) Pengumpulan data 6) Analisis data, 7) Matriks dan pengujian kesimpulan (Asep Suryana, 2007). Penelitian yang digunakan penulis merupakan penelitian kualitatif di mana dalam langkah-langkah penelitiannya menggunakan langkah-langkah seperti yang disarankan oleh Miles dan Huberman tersebut. Data yang digunakan penulis merupakan data non angka yang dikumpulkan dan diolah menggunakan konsep dan teori yang berkaitan dan akhirnya dapat diketahui hasilnya melalui proses analisis.

Penelitian ini merupakan jenis penelitian eksplanatif, di mana penelitian ini menjelaskan hubungan antar variabel. Variabel dependen atau unit analisa penelitian ini berada pada level kelompok negara, yaitu alasan atau dasar pertimbangan dikeluarkannya kebijakan embargo ekonomi oleh EU terhadap Rusia. Sedangkan variabel independen atau unit eksplanasi pada penelitian ini berada pada level kelompok negara, yaitu sanksi embargo ekonomi EU terhadap Rusia. Sehingga penelitian ini menggunakan model penelitian korelasionis, di mana unit analisa dan unit eksplanasi pada penelitian ini berada pada level yang sama.

Dalam level analisa UE berada pada level kelompok negara karena UE terdiri atas beberapa negara. Sedangkan dalam konteks pengaplikasian teori, penulis menganalogikan UE sebagai sebuah negara karena kesamaan strukturnya dengan 
negara. Sehingga dalam proses pengambilan kebijakannya dapat dianalogikan sebagai suatu negara.

\section{Dinamika Hubungan Uni Eropa dengan Ukraina}

Hubungan antara Uni Eropa (UE) dan Ukraina mengalami pasang surut seiring dengan pergantian rezim yang memerintah. Pasca runtuhnya Uni Soviet dan pecahnya Ukraina dari Rusia perjanjian pertama antara Ukraina dengan UE adalah the Partnership and Co-Operation Agreement pada tahun 1994. Perjanjian ini membahas mengenai kerja sama teknis dan non-teknis antara UE dengan Ukraina, di mana Ukraina akan mendapat bantuan dana dari UE serta merupakan perjanjian awal dalam hubungannya dengan UE (Daniel Hatton, 2010:8). Selanjutnya pada masa pemerintahan Viktor Yushchenko (2004-2010), Ukraina dan UE mulai membahas tentang pembangunan zona perdagangan bebas yang akhirnya pada 9 September 2008 melahirkan kesepakatan antara Ukraina dan UE yaitu Perjanjian Asosiasi Eropa (Association Agreement) yang rencananya akan ditandatangani pada akhir tahun 2013 (Octab Alfiansyah, 2015).

Ukraina mengalami pergantian rezim dari Viktor Yushchenko ke presiden baru yaitu Viktor Yanukovych yang mengubah arah kebijakan Ukraina yang pada rezim sebelumnya lebih condong ke UE berubah menjadi lebih condong ke Rusia. Hal itu membuat Yanukovych mengeluarkan kebijakan Ukraina keluar dari perjanjian Asosiasi Eropa yang sebelumnya telah disepakati dan akan ditandatangani pada 21 Desember 2013. Hal tersebut kemudian memicu protes besar-besaran di ibukota Ukraina, Kiev (Kompas, 13 Desember 2013:11).

Dikarenakan protes berlangsung secara terus menerus, Parlemen Ukraina akhirnya mengeluarkan kebijakan untuk memecat Yanukovych pada 22 Februari 2014 (indonesia.mfa.gov.ua, 2014). Parlemen Ukraina kemudian menunjuk Oleksandr Turchnyov sebagai presiden sementara di Ukraina (Palupi Annisa Auliani, 2014). Selanjutnya Ukraina berada pada masa kepemimpinan Petro Poroshenko yang terpilih menjadi presiden pada pemilu Mei 2014 di Ukraina di mana kebijakan yang diambil oleh Poroshenko cenderung dekat dengan UE (voaindonesia.com 2014.a). Pemecatan Yanukovych menyebabkan banyak kota-kota di Ukraina yang melakukan referendum untuk memisahkan diri dari Ukraina, di antaranya adalah Crimea. 


\section{Konflik Domestik Ukraina}

Crimea yang lebih mendukung terhadap kebijakan Yanukovych untuk membatalkan perjanjian Asosiasi Eropa, akhirnya melakukan referendum untuk bergabung dengan Federasi Rusia (Kompas, Kamis 20 Maret 2014:9). Keinginan mereka untuk bergabung tersebut dilatarbelakangi oleh dua faktor. Pertama, Crimea yang secara historis merupakan bagian dari Rusia, sehingga wilayah tersebut memiliki ikatan yang erat dengan Rusia. Kedua, ketidaksepakatan mereka atas pemecatan Presiden Yanukovych di mana Yanukovych merupakan Presiden Ukraina yang dapat membawa mereka untuk tetap menjalin hubungan baik dengan Rusia. Hal ini dikarenakan Yanukovych selalu membuat kebijakan yang cenderung dekat dengan Rusia (Kompas, Kamis 20 Maret 2014:9).

Referendum yang diselenggarakan oleh Crimea diikuti oleh sekitar 1,5 juta warga. Referendum tersebut dilaksanakan pada 16 Maret 2014 di 27 tempat pemungutan suara di seluruh wilayah Crimea (Maria Rita Hasugian, 2014). Hasil dari referendum tersebut adalah 97 persen dari pemilih menyatakan diri mendukung keputusan untuk keluar dari Ukraina dan bergabung dengan Federasi Rusia (indonesia.irib.ir, 2014). Selanjutnya, Crimea secara resmi menjadi bagian Federasi Rusia pada 21 Maret 2014 pasca ditandatanganinya dokumen resmi sebagai undangundang hasil referendum tersebut oleh Putin, Presiden Rusia (kompas.com, 2014). Akan tetapi, Ukraina dan UE tidak mengakui adanya hasil referendum tersebut dan menganggap referendum tersebut ilegal dan tidak sah (BBC, 2014.b).

Adanya referendum Crimea pada akhirnya mendorong beberapa wilayah lain seperti di Kota Donetsk, Sloviansk (okezone.com, 2014.b) dan Luhansk untuk melakukan referendum pemisahan diri dari Ukraina serta bergabung dengan Rusia (okezone.com, 2014.a). Hal ini menyebabkan terjadinya perang saudara antar warga Ukraina sendiri. Seperti yang terjadi pada 2 Juni 2014, bentrokan antara kelompok masyarakat pro-Rusia yang diserbu oleh tentara Ukraina di Kota Luhansk, Kota Donetsk dan Slavyansk. Korban yang meninggal dalam pertempuran Donetsk dan Luhansk yang terjadi sejak April 2014 ini adalah 181 serta korban luka sebnyak 292 orang. Sedangkan di Slavyansk korban sebanyak 14 serdadu termasuk seorang jendral militer dari Ukraina (dw.com, 2014.a). Selain di ketiga kota tersebut, pada 19 juni 2014 bentrokan juga terjadi di dekat Kota Krasny Liman (Muhaimin, 2014). Bentrokan 
kembali terjadi pada 5 September 2014 yaitu pertempuran perebutan Kota Pelabuhan Mariupol oleh pasukan masyarakat Ukraina yang pro-Rusia dengan pasukan tentara Ukraina yang memakan puluhan korban (Ani Nursalikah, 2014).

\section{Keterlibatan Uni Eropa dan Posisi Startegis Ukraina bagi Uni Eropa}

Keterlibatan UE dalam konflik tersebut adalah ketika UE bersama dengan Ukraina menyatakan bahwa referendum yang dilakukan oleh Crimea merupakan referendum ilegal dan tidak sah. Selanjutnya UE melakukan protes dengan adanya hal tersebut dengan cara memberikan tekanan kepada Rusia untuk berhenti melakukan intervensi dalam konflik domestik tersebut. Tekanan yang diberikan UE di antaranya yaitu pemberian sanksi pembekuan aset dan visa serta embargo ekonomi terhadap Rusia. Selain itu, ketika konflik berlangsung, UE juga memberikan bantuan dana sebesar 1,8 miliar Euro kepada Ukraina. Bantuan lain yaitu UE berjanji akan membantu menyelesaikan sengketa gas Ukraina dan Rusia (Kunto Wibisoo, 2016). Melalui IMF (International Monetary Fund), UE dan 24 negara anggota IMF juga menyepakati pemberian bantuan dana sebesar 17,1 miliar dollar kepada Ukraina (vibiznews.com, 2014.b).

Bagi UE, Ukraina merupakan wilayah yang sangat penting sebagai bentuk pengakuan power dan perluasan pengaruh UE di Eropa Timur yang merupakan wilayah yang menjadi perebutan pengaruh antara UE dan Rusia. UE mulai melakukan pendekatan kepada Ukraina yang merupakan bagian dari salah satu negara eks-Soviet untuk menyebarkan ideologi demokrasi dan liberalisme yang dianut oleh negara-negara Eropa (M. Arif Pranoto, 2014). Perebutan pengaruh ideologi antara Timur dan Barat tersebut sudah terjadi sejak dulu (David Matsaberidze, 2015). Meskipun saat ini penyebaran ideologi tidak lagi menjadi perhatian utama UE dan Rusia, akan tetapi Rusia tetap dianggap sebagai ancaman bagi UE.

Selain itu, seperti yang telah dijelaskan sebelumnya, di Ukraina terdapat tiga jaringan pipa gas yang mengalirkan gas dan minyak dari Rusia ke Uni Eropa. Sehingga secara ekonomi, selain untuk memperluas wilayah pasar bebas UE, kedekatan Ukraina dengan UE juga akan membantu UE dalam distribusi energi yang dibutuhkan oleh UE dari Rusia melalui Ukraina. Hal inilah yang pada akhirnya mendorong UE melakukan intervensi dalam konflik domestik di Ukraina. 


\section{Keterlibatan Rusia dan Posisi Strategis Ukraina Bagi Rusia}

Konflik yang terjadi di Ukraina pada mulanya merupakan konflik domestik, di mana terjadi pro dan kontra atas kebijakan Presiden Yanukovych yang menyatakan Ukraina keluar dari Perjanjian Asosiasi Eropa (Kompas, 13 Desember 2013:11). Keputusan tersebut diambil oleh Yanukovych atas tekanan yang diberikan oleh Rusia (BBC, 2014). Kelompok yang kontra terhadap kebijakan tersebut melakukan demonstrasi dan menuntut diturunkannya Yanukovych dari jabatannya sebagai presiden.

Protes serta demonstrasi tersebut menyebabkan Ukraina mengalami krisis dalam negeri. Sehingga pada 17 Desember 2013 Rusia memberikan bantuan uang dalam bentuk hutang untuk Dana Kesejahteraan Sosial di Ukraina sebesar 15 miliar dollar AS serta memberikan subsidi sebesar 33 persen sehingga harga gas yang semula 400 dolar AS tiap 1000 meter kubik menjadi 268,5 dollar AS (nids.mod.go.jp, 2015:207).

Akhirnya pada 22 Februari 2014 parlemen Ukraina mengeluarkan kebijakan untuk memecat Presiden Yanukovych (BBC, 2014.a). Pasca diturunkannya Yanukovych menjadi presiden, Rusia yang mendukung keputusan Yanukovych keluar dari Perjanjian Asosiasi Eropa kemudian membatalkan kesepakatannya dengan Ukraina dalam pemberian hutang \$15 miliar dolar. Meskipun dana hutang tersebut sudah cair 3 miliar dolar pada Desember 2013 (Steven Wahroel, 2014:5).

Bagi Rusia, Ukraina merupakan wilayah yang sangat penting dalam politik, ekonomi serta militer negaranya. Dalam hal ekonomi, Ukraina merupakan jembatan penghubung yang menyalurkan gas dari Rusia ke Eropa (Octab Alfiansyah, 2015:318). Selain itu keadaan ekonomi Ukraina yang bergantung pada ekspor baja, batu bara, bahan bakar dan minyak bumi, bahan kimia serta biji-bijian ke Rusia memberi keuntungan tersendiri bagi Rusia(Muhammad Fadly, 2015:4).

Gambar 1 menunjukkan peta pipa gas yang menyalurkan gas dan minyak dari Rusia menuju negara-negara Uni Eropa. Hal ini menunjukkan bahwa Ukraina merupakan wilayah transit energi yang strategis bagi Rusia maupun Uni Eropa. Dalam hal militer, Ukraina merupakan wilayah yang penting bagi Rusia, terutama Crimea yang menjadi wilayah strategis bagi Angkatan laut Rusia (jakartagreater.com, 2014). Ukraina merupakan benteng alami dan negara penyangga bagi Rusia (buffer zone state). Bagi 
Rusia, Ukraina merupakan salah satu negara yang penting untuk menunjukkan power dan pengaruhnya di Eropa Timur sebagai salah satu negara eks-Soviet.

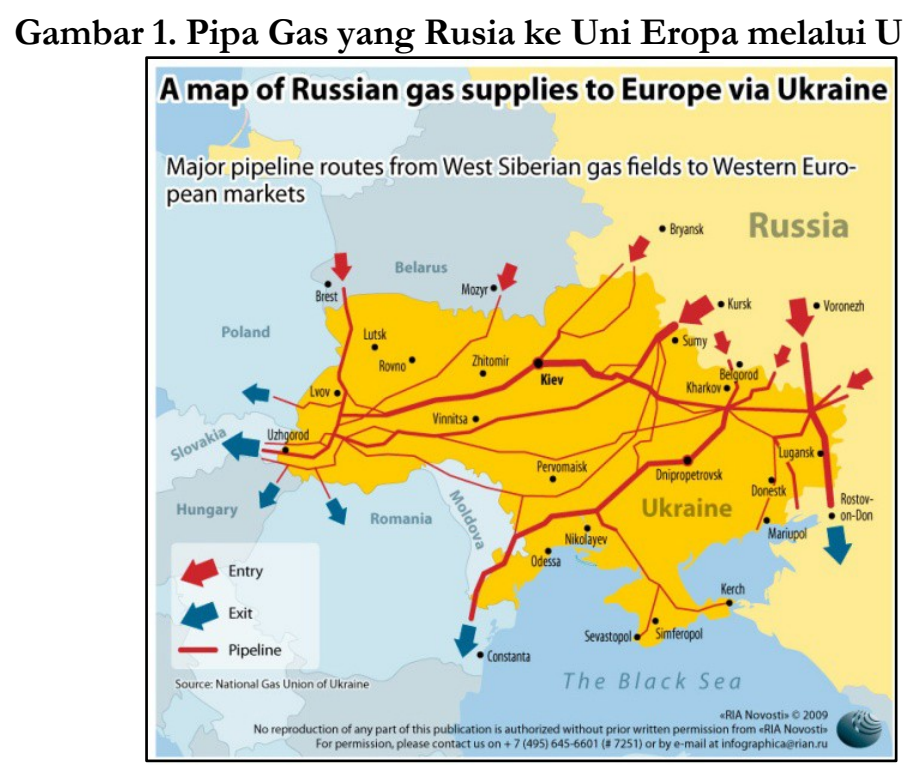

Sumber: zerohedge.com, 2014

Intervensi yang dilakukan Rusia dalam konflik domestik Ukraina tidak hanya sebatas intervensi politik, akan tetapi berlanjut pula dengan intervensi militer. Atas dasar permintaan PM Ukraina, Sergei Aksenov. Rusia mengirim tentara sebanyak 30.000 tentara ke semenanjung di tepi Laut Hitam (Kompas, Kamis 20 Maret 2014:9). Selanjutnya pada Sabtu, 22 Maret 2014 pasukan elit Rusia merebut pangkalan Belbek di Crimea (Kompas, Kamis 20 Maret 2014:9). Atas intervensinya tersebut, Rusia menjadi terancam akan dikeluarkan dari keanggotaanya di G8 (Kompas, 24 Maret 2014:10). Selanjutnya, Rusia mengirimkan tentaranya untuk membantu setiap pertempuran masyarakat pro-Rusia dengan para tentara Ukraina. Atas intervensi militernya tersebut, UE menjatuhkan sanksi embargo ekonomi terhadap Rusia. Hal ini berdampak buruk bagi kerja sama ekonomi antara UE dan Rusia yang telah terbangun sejak lama.

\section{Kebijakan Embargo Ekonomi Uni Eropa Terhadap Rusia}

Pasca diadakannya referendum di Crimea, Rusia yang mengakui referendum tersebut sah menyatakan Crimea sebagai negara merdeka yang tergabung 
dalam Federasi Rusia. Hal ini dianggap sebuah pencaplokan wilayah dan tidak sah oleh UE dan Ukraina. Atas dasar itulah UE memberikan sanksi terhadap Rusia berupa sanksi ekonomi yaitu pembekuan aset beberapa perusahaan dan individu Rusia serta larangan masuk ke UE terhadap pejabat tinggi Rusia (Fadli Adzani, 2015). Sanksi tersebut mulai diberlakukan sejak 17 Maret 2014 (Steven Wahroel, 2014:7).

UE memperluas sanksi yang diberikan kepada Rusia karena Rusia tak kunjung menghentikan campur tangannya di Ukraina Timur yaitu UE melarang seluruh negara anggotanya untuk mengimpor senjata dari Rusia (Dimitry Litovkin, 2014). Akses bank pemerintah Rusia terhadap modal juga dibatasi (BBC, 2014.d). Perusahaan besar minyak dan gas Rusia tidak akan mendapat kredit dari UE lagi. Perusahaan gas yang mendapat sanksi yaitu Gazprom, Rosneft serta Transneft. Sedangkan dalam kerja sama militer, UE memutuskan hubungan kerja sama dengan perusahaan penerbangan United Airport Corporation, serta perusahaan senjata Kalashnikov (dw.com, 2014.b). Dengan adanya sanksi tersebut Rusia balik mengancam UE. Rusia melarang semua penerbangan dari Eropa ke Rusia. Rusia juga memotong aliran gas ke Polandia dan Austria. Rusia menerapkan kebijakan memotong aliran gas ke Polandia sebesar 50\%. Sedangkan di Austria mendapat pengurangan sebesar 15\% dari jumlah yang seharusnya diterima (dw.com, 2014.b).

Dalam teori Foreign Policy Strategy yang dikemukakan oleh Lovell, strategi yang diterapkan oleh suatu negara dalam berinteraksi dengan negara lain ditentukan oleh dua faktor. Pertama, persepsi para pembuat kebijakan terhadap kapabilitas negara sendiri. Hal ini dapat dilihat dari kemampuan dalam negeri yang menunjukkan kapabilitas tersebut. Kedua, bagaimana suatu negara melihat posisi negara lain bagi negara sendiri yang dalam hal ini terbagi menjadi dua, yaitu mengancam dan mendukung (John P. Lovell, 1970:98-99). Berikut merupakan pertimbangan strategi UE dalam memberikan sanksi embargo ekonomi terhadap Rusia.

\section{Kekuatan Energi Rusia serta Posisi Uni Eropa (UE) dalam Perspektif Rusia}

Rusia memiliki cadangan gas alam terbesar di seluruh dunia yaitu 1,688 triliun kaki kubik (www.iea.gov, n.d., a). Dengan cadangan yang besar tersebut, Rusia mampu memproduksi sebanyak 10.847 ribu barel per hari dan berada pada urutan ketiga sebagai produsen gas terbesar di dunia. Ukraina merupakan negara yang 
memasok gas dari Rusia ke UE. Sekitar 65 miliar meter kubik dari 133 miliar meter kubik gas dialirkan dari pipa-pipa gas melalui Ukraina ke 28 negara anggota UE setiap tahunnya (Tia Mutiasari, 2014). Dengan fakta tersebut maka Rusia merupakan negara superpower di bidang energi (Andi Rafael Saputra, 2014:110-144).

Tabel. 1. Statistik Energi Rusia

\begin{tabular}{|c|c|c|}
\hline Energi Rusia & Jumlah & Peringkat di Dunia \\
\hline Total konsumsi energi primer & 30,495 kuadriliun Btu & $3(2013)$ \\
\hline Produksi gas alam kering & 20.437 milyar kaki kubik & $2(2014)$ \\
\hline $\begin{array}{l}\text { Total produksi petrolium dan } \\
\text { produksi cairan lainnya }\end{array}$ & 10.847 ribu barel per hari & $3(2014)$ \\
\hline Produksi batubara primer & 388.013 ribu ton & $6(2013)$ \\
\hline Cadangan gas alam terbukti & & $1(2015)$ \\
\hline
\end{tabular}

Eropa memasok sekitar 40\% kebutuhan gasnya serta 30\% kebutuhan minyaknya dari Rusia (Andi Rafael Saputra, 2014:110-144). Terdapat lebih dari sembilan negara anggota Uni Eropa yang bergantung pada pasokan gas dan minyak mentah yang berasal dari Rusia tersebut (BBC, 2006), sebagaimana tampak dalam tabel 2.

Tabel 2. Ketergantungan Negara-negara Anggota UE Terhadap Pasokan Gas Rusia

\begin{tabular}{c|l|c} 
No. & \multicolumn{1}{|c|}{ Negara } & $\begin{array}{c}\text { Jumlah } \\
\text { Ketergantungan } \\
\text { Dalam Persen }\end{array}$ \\
\hline 1 & Latvia & $100 \%$ \\
\hline 2 & Estonia & $100 \%$ \\
\hline 3 & Slovakia & $100 \%$ \\
\hline 4 & Finlandia & $100 \%$ \\
\hline 5 & Bulgaria & $80 \%$
\end{tabular}




\begin{tabular}{c|l|c}
6 & Lithuania & $80 \%$ \\
\hline 7 & Republik Czech & $80 \%$ \\
\hline 8 & Yunani & $60 \%$ \\
\hline 9 & Austria & $60 \%$ \\
\hline 10 & Hongaria & $60 \%$ \\
\hline 11 & Jerman & $39 \%$ \\
\hline 12 & Italia & $38 \%$
\end{tabular}

Diolah dari berbagai sumber

Berdasarkan penjelasan di atas, dalam perspektif Rusia kapabilitas negaranya lebih tinggi daripada UE. Hal ini dikarenakan Rusia memiliki kekuatan yang besar pada sektor gas dan energi. Rusia juga memiliki kekuatan militer yang cukup kuat di mana Rusia mewarisi sekitar 50\% aset di bidang persenjataan dan ekonomi Uni Soviet (Andi Rafael Saputra, 2014:110-144). Ketergantungan UE yang tinggi terhadap suplai gas Rusia juga menjadi kekuatan dan bargaining position tersendiri bagi Rusia dalam kerja samanya di sektor energi dengan UE. Sedangkan, proses perluasan pengaruh UE ke Eropa Timur dalam rangka EU Enlargement dipandang sebagai bentuk penghinaan yang merusak power dan hegemoni Rusia di kawasan Eropa Timur. Dalam perspektif Rusia, kedekatan UE dengan Ukraina sebagai ancaman bagi negaranya. (Dinna Wisnu, 2014)

\section{Posisi Rusia dalam Perspektif Uni Eropa (UE)}

Rusia merupakan negara yang mewarisi kekuatan persenjataan sekaligus ekonomi Uni Soviet (Andi Rafael Saputra, 2014:110-144). Rusia berada dalam urutan kedua dari deretan negara yang memiliki kekuatan militer terkuat di dunia. Pada tahun 2013 rangkingnya berada pada urutan setelah Amerika Serikat (Andi Rafael Saputra, 2014:110-144). Selain itu, Rusia juga merupakan negara adidaya nuklir (Jim Nichol, 2014).

Kekuatan energi Rusia tersebut membuat UE mengalami dilema dalam pengambilan kebijakan terkait intervensi Rusia terhadap konflik domestik Ukraina serta aneksasi Rusia atas Crimea di mana UE memiliki ketergantungan yang besar pada 
suplai energi Rusia. Sedangkan di sisi lain UE juga harus melindungi kepentingan politiknya atas Ukraina. Sehingga bagi UE, Rusia menghadirkan dua ancaman yaitu pertama, ancaman kehilangan dan kekurangan pasokan energi dari Rusia jika kebijakan yang diambil UE atas tindakan intervensi Rusia di Ukraina merugikan Rusia. Kedua, ancaman gagalnya integrasi UE dengan Ukraina. Adanya ancaman dari Rusia tersebut pada akhirnya membawa UE untuk mencari mitra kerja sama lain untuk memenuhi kebutuhan energi negara anggotanya.

\section{Strategi Konfrontasi Uni Eropa (UE) terhadap Rusia}

\section{a. Strategi Pengamanan Energi Uni Eropa}

Total semua kebutuhan energi UE, sebanyak 53\% diperoleh dari impor. Sementara 47\% sisanya diperoleh dari produksi domestik. Impor energi UE berupa: 90\% minyak mentah, $66 \%$ gas alam, $42 \%$ batubara dan bahan bakar padat lainnya, $40 \%$ uranium dan bahan bakar nuklir lainnya (ec.europa.eu, n.d., a)

\section{Gambar 2. Diagram Tujuan Ekspor Minyak Mentah dan Kondensat Rusia Tahun 2014}

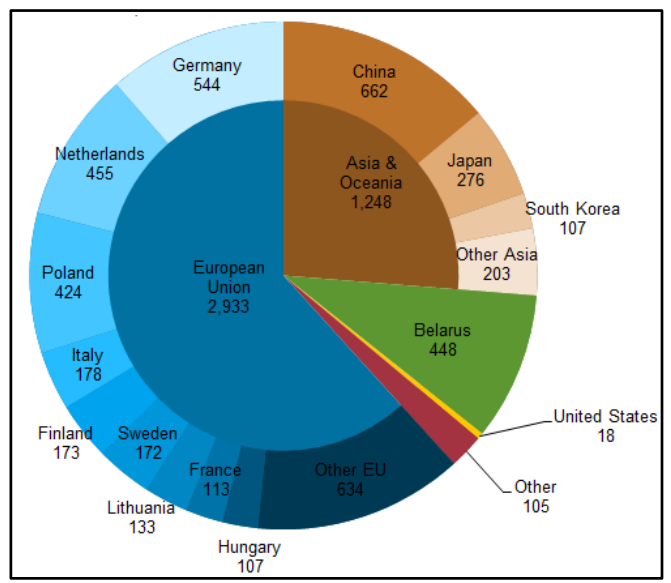

(Sumber: www.eia.gov, n.d., c)

UE merupakan kawasan tujuan utama ekspor gas dan sumber energi lain dari Rusia. Diagram 3.1 menunjukkan bahwa negara-negara UE merupakan pasar potensial bagi Rusia. Lebih dari 50\% minyak mentah dan gas kondensat (gas hasil dari penyulingan) Rusia di ekspor ke UE dan sebagian besar diekspor ke Jerman, Belanda dan Polandia. Diagram tersebut menunjukkan bahwa jika terjadi pemutusan kerja 
sama, maka yang akan merugi adalah Rusia karena UE merupakan pasar potensial dan hampir 50\% ekspor energi Rusia mengalir ke UE.

Dalam menghadapi ancaman kekurangan gas akibat konflik, UE melakukan berbagai strategi yang dapat membantu negara-negara anggotanya bertahan dari kondisi tersebut. Salah satu di antara strategi tersebut adalah melakukan stress test, yaitu latihan kondisi darurat energi, di mana dalam tes ini disimulasikan UE mengalami gangguan pasokan energi. Dalam simulasi tersebut UE membuat dua skenario gangguan, pertama UE tidak akan mendapat pasokan gas selama enam bulan dari Rusia serta kedua, UE akan mengalami gangguan pasokan gas melalui transit Ukraina. Hasilnya adalah adanya dampak besar terhadap negara anggota UE, terutama yang berada di wilayah Timur Uni Eropa yang notabene memiliki ketergantungan yang besar terhadap suplai gas Rusia (ec.europa.eu, n.d., b). Sehingga untuk mengantisipasi itu UE melakukan antisipasi untuk keamanan energi jangka panjang dan jangka pendek di antaranya yaitu menjalin kerja sama yang lebih erat dengan negara-negara penyuplai energi untuk wilayahnya serta meningkatkan produksi energi dalam negeri (ec.europa.eu, 2014).

Selanjutnya UE melakukan kerja sama energi dengan negara-negara penghasil minyak di Asia Tengah. Kebutuhan gas UE yang berasal dari Asia Tengah didapatkan dari Turkmenistan, Azerbaijan, Kazakhstan, dan Uzbekistan. Di antara negara-negara tersebut, Turkmenistan merupakan negara Asia Tengah yang memiliki cadangan minyak sekitar 600 juta barel pada tahun 2015. Sedangkan cadangan gas alamnya mencapai 265 triliun kaki kubik (Tcf) dan menempati urutan keenam di dunia. Menurut data tahun 2014, dalam sehari negara ini mampu memproduksi hingga 238.000 barel minyak (www.eia.gov, n.d., b) Dengan posisi sebagai pemilik cadangan minyak urutan keenam di dunia, UE lebih meningkatkan kerja sama dengan Turkmenistan. Hubungan kerja sama antara UE dengan Turkmenistan mulai terbangun sejak tahun 2007, yaitu pasca diadakannya pertemuan Menlu UETurkmenistan di Ashgabat, Turkmenistan (indonesia.cri.cn, 2008). Selain Turkmenistan, UE juga mempererat kerja sama dengan negara penghasil minyak lainnya di Asia Tengah.

Kemudian, kedekatan hubungan negara-negara Asia Tengah dengan UE yang semakin erat terlihat melalui kerja sama di bidang energi melalui Nubacco Project, 
(pipelinesinternational.com, n.d.) Galsi Pipeline, Medgaz Pipeline, Interconnection Turkey Greece Italy (ITGI) Pipeline, The Azerbaijan - Georgia - Romania Interconnection (AGRI) LNG Project, The Trans Adriatic Pipeline (TAP), serta proyek The White Stream Gas Pipeline (pipelinesinternational.com, n.d.).

Selain melakukan kerja sama dengan negara-negara penghasil minyak di Asia Tengah, UE juga melakukan kerja sama energi dengan Norwegia dan negaranegara Organization of Petrolium Exporting Countries (OPEC). OPEC merupakan sebuah organisasi perkumpulan negara-negara pengekspor minyak yang terdiri atas 12 negara anggota. Dalam kerjasamanya dengan UE, OPEC memberikan sekitar 40\% dari total impor minyak mentah UE. Arab Saudi, Libya, dan Nigeria merupakan pemasok minyak mentah terbesar di antara semua negara anggota OPEC. Uni Eropa bertemu dengan OPEC setiap tahun di tingkat menteri untuk membahas berbagai masalah mengenai kerja sama minyak keduanya (ec.europa.eu, n.d., c).

Norwegia merupakan negara Eropa yang tergabung dalam European Economic Area (EEA) (eeas.europa.eu, n.d.). Norwegia merupakan penyuplai minyak terbesar bagi UE, di mana suplai minyaknya setara dengan suplai yang diberikan Rusia, yaitu sebesar 40\% dari total impor minyak UE. UE dan Norwegia juga bekerja sama dalam membangun pipa yang akan mengalirkan minyak dari Norwegia ke UE, di antaranya yaitu The Baltic Pipe serta proyek The Skanled Pipeline (pipelinesinternational.com, n.d.).

Menguatnya kerja sama tersebut memberikan dua keuntungan sekaligus bagi UE, yaitu mengatasi ketergantungan sekaligus melemahkan ekonomi Rusia yang bergantung pada ekspor gas. Pasca adanya embargo tersebut, mata uang Rubel yang merupakan mata uang Rusia mengalami penurunan nilai kurs terhadap Dollar AS. Tahun 2013 kurs Rubel terhadap dollar AS 30-32 Rubel per Dollar AS, maka pada tahun 2014 mencapai 36 Rubel per dollar AS (medanbisnisdaily.com, 2014). Selain itu harga minyak juga menurun drastis, dari yang semula mencapai 100 dollar AS per barel merosot menjadi kurang dari 60 dollar AS per barel (vibiznews.com, 2014.a). Hal ini membuat Rusia mengalami inflasi mencapai 7\% (medanbisnisdaily.com, 2014). Ini menunjukkan bahwa UE tidak powerless meskipun Rusia menghentikan pasokan gasnya. Bukti bahwa dengan embargo ekonomi UE atas Rusia tersebut mempengaruhi melemahnya kurs Rubel atas dollar AS. 


\section{b. Dukungan North Atlantic Treaty Organization (NATO) Atas Kebijakan Embargo Ekonomi Uni Eropa (UE) Terhadap Rusia}

NATO merupakan aliansi militer kawasan Atlantik Utara yang dipelopori oleh Amerika Serikat dibentuk untuk menanggapi ancaman yang ditimbulkan oleh Uni Soviet (www.nato.int, n.d., a). Tujuan utama NATO adalah untuk menjaga keamanan dan kebebasan negara-anggotanya melalui sarana politik dan militer (www.nato.int, n.d., e). Hubungan antara UE dengan NATO didasari oleh prinsip-prinsip politik yang ditandatangani dalam sebuah deklarasi pada Desember 2002. Deklarasi tersebut mereka beri nama European Security and Deffense Policy (ESDP). NATO dan UE bekerjasama juga atas dasar kepentingan strategis dan nilai-nilai bersama (www.nato.int, n.d., c).

Dengan metode yang berbeda, mereka secara bersama membantu menyelesaikan konflik Ukraina, NATO menggunakan kekuatan militer sedangkan UE tidak (Johannes Sutanto de Britto, 2015). Dalam konflik Ukraina, pasca bersatunya Crimea dengan Rusia, NATO menambah jumlah militernya di perbatasan Rusia. NATO juga secara khusus mengirim kapalnya untuk patroli udara di Laut Hitam (Aningtias Jatmika, 2014). Selain itu NATO juga memberikan latihan militer kepada tentara Ukraina pada Juni 2014 (Paul Belkin et.all, 2014). Bentuk dukungan NATO yang lain adalah adanya aliansi antara NATO dengan negara-negara Asia Tengah dan negara-negara Kaukasus di mana negara-negara tersebut juga menjalin kerja sama yang erat di bidang energi dengan UE (www.nato.int, n.d., b).

\section{c. EU Enlargement Sebagai Simbol Superioritas Uni Eropa (UE) atas Rusia}

European Union (EU) Enlargement merupakan sebutan untuk aksi perluasan keanggotaan UE di Eropa, terutama di Eropa bagian Timur. Perluasan UE terbagi dalam lima periode, yaitu perluasan pertama di mana EU masih dalam bentuk EC yang menjadikan EC pada masa ini (1972) memiliki 9 negara anggota. Perluasan kedua terjadi pada tahun 1970-an yang berhasil membuat Yunani menjadi anggota EC. Selanjutnya perluasan ketiga terjadi pada 1986 yang ditandai dengan bergabungnya Spanyol dan Portugal. Perluasan keempat terjadi antara tahun 1990-an di mana EC sudah menjadi EU dan anggota baru pada gelombang ketiga ini adalah Austria, 
Finlandia dan Swedia. Perluasan terakhir terjadi pada tahun 2000-an di mana 10 negara Eropa bergabung dengan UE secara massal pada 2004 diikuti oleh Romania dan Bulgaria pada 2007 serta Kroasia pada 2013. (Duncan Watts, 2008). Dalam prosesnya EU Enlargement diawali oleh pengajuan proposal keanggotaan oleh negara pemohon. Permohonan tersebut bisa diterima dan bisa ditolak tergantung kesesuaian negara pemohon dengan kriteria yang diberikan oleh UE untuk menjadi kandidat negara anggotanya. Kebijakan UE terhadap negara calon anggota yaitu negara tersebut harus menerapkan Copenhagen Criteria yang isinya adalah 1. negara anggota harus mempunyai institusi yang stabil dan menjamin demokrasi, hukum dan HAM serta meghargai kaum minoritas. 2. Ekonomi pasar yang baik dan mampu bersaing dalam pasar bebas UE. 3. Kemamupuan melaksanakkan tugas sebagai negara anggota UE (Lailatur Riva, 2012).

Ukraina misalnya, intensi untuk bergabung dalam keanggotaan UE ditunjukkan dengan meratifikasi perjanjian kerja sama ekonomi Assosiasi Eropa (European Assosiation Agreement). Selain itu, pada 25 September 2014 melalui pernyataan Presiden Petro Poroshenko, Ukraina telah mendeklarasikan akan bergabung dengan UE pada tahun 2020 (voaindonesia.com, 2014.b). Kecenderungan negara-negara yang dikenal berada di bawah pengaruh Rusia terhadap UE, baik dalam skema kerja sama NATO maupun UE enlargement menunjukkan legitimasi power dan pengaruh UE terhadap mereka lebih besar daripada pengaruh Rusia sendiri (Shinta Sinaga, 2014).

Pengakuan power UE melalui perluasan keanggotaannya ditunjukkan dengan kesanggupan negara-negara tersebut memenuhi conditional member of EU. Negara-negara tersebut harus melakukan program penyesuaian (EU adjusment program) dengan cara mengubah sistem politik dan pemerintahannya dengan memenuhi standar demokrasi dan liberalisasi sebagai syarat bergabung dalam pasar UE. Sedangkan untuk negara anggota, UE memiliki kebijakan yaitu: 1. Market Building Process yang berisi pembentukan pasar tunggal, harmonisasi dan perlindungan konsumen, kebijakan kompetisi, kebijakan perhubungan bersama, kesatuan ekonomi dan moneter (the single currency), agrikultur (the agricultural policy), perikanan (Common Fisheries Policy), kebijakan lingkungan, kebijakan kawasan, serta kebijakan 
sosial. 2. Second and Third Pillar Policies yang berisi keamanan internal serta pertahanan dan kebijakan luar negeri (Lailatur Riva, 2012).

Dengan berbagai fakta tersebut membuktikan bahwa embargo ekonomi UE terhadap Rusia merupakan strategi konfrontasi UE terhadap Rusia. Hal ini dibuktikan dengan adanya pertimbangan yaitu kapabilitas UE yang lebih tinggi daripada Rusia. Buktinya yaitu kerja sama UE dengan NATO dalam hal militer untuk menyaingi Rusia serta kerja sama UE dengan Turkmenistan serta negara-negara Asia Tengah penghasil minyak lainnya untuk mengatasi ketergantungan energinya terhadap Rusia. Selain itu, adanya EU enlargement merupakan bentuk pengakuan power UE atas wilayah Eropa, yang dibuktikan dengan banyaknya negara-negara Eropa yang ingin bergabung dalam keanggotaan UE.

\section{Kesimpulan}

Adanya konflik domestik di Ukraina yang menyebabkan intervensi Rusia dan Uni Eropa atas konflik tersebut merupakan fakta bahwa konflik yang terjadi di Ukraina merupakan konflik antara UE dan Rusia. Dalam hal ini Ukraina merupakan medan dari konflik yang sesungguhnya. Konflik ini diawali oleh keinginan Ukraina yang ingin berintegrasi lebih dekat dengan UE. Hal ini menyebabkan kemarahan Rusia, sehingga atas desakan Rusia akhirnya Ukraina menyatakan diri keluar dari Perjanjian Asosiasi Eropa yang merupakan pintu masuk integrasi Ukraina dengan Uni Eropa.

Keterlibatan Rusia tersebut menuntut UE untuk ikut serta dalam konflik tersebut yaitu dengan memberikan embargo ekonomi kepada Rusia. Hal ini dikarenakan UE menganggap Rusia merupakan penghalang atas misi enlargement-nya. Keputusan embargo ekonomi tersebut merupakan strategi konfrontasi yang diterapkan UE kepada Rusia. Hal ini dibuktikan dengan dua pertimbangan yang mendasari keputusan tersebut, yaitu anggapan bahwa Rusia merupakan ancaman bagi UE serta kapabilitas UE yang lebih tinggi daripada Rusia.

Kapabilitas UE yang tinggi ditunjukkan dengan adanya kerja sama energi UE dengan negara lain dapat membantu UE lepas dari ketergantungan energinya terhadap Rusia. UE juga mendapat dukungan militer dari NATO dalam menghadapi Rusia, serta adanya EU enlargement yang merupakan pembuktian power UE di mana 
banyak negara Eropa, khususnya Eropa Timur tertarik untuk berintegrasi lebih dekat dengan UE.

\section{Daftar Pustaka}

\section{Buku}

Lovell, J.P. (1970). Foreign Policy in Perspective: Strategy, Adaptation, Decision Making. New York: Holt, Rinehalt and Winston, Inc,.

Saputra, A.R. (2014). Dari Uni Soviet Hingga Rusia. Jogjakarta: PALAPA.

Schneider, C.J. (2009). Conflict, Negotiation and European Union Enlargement. New York: Cambridge University Press.

Watts, D. (2008). The European Union. Edinburgh: Edinburgh University Press Ltd.

\section{Koran Cetak}

AS Ancam Beri Sanksi Ukraina. Koran Kompas. edisi 13 Desember 2013.

Rusia Balik Mengancam. Koran Kompas. edisi Kamis 20 Maret 2014.

Rusia Rebut Lanud Belbek. Koran Kompas. edisi 24 Maret 2014.

\section{Skripsi}

Riva, L. (2012). Dampak Perluasan Uni Eropa ke Negara-negara Baltik terbadap Soft Security Rusia. Skripsi: FISIP Hubungan Internasional. UMM.

Setiawan, A.Y. (2014). Intervensi Politik Rusia Terbadap Proses Pemilu di Ukraina. Skripsi: FISIP Hubungan Internasional. UMM.

\section{Website}

A Short History of NATO. http://www.nato.int/history/nato-history.html (a) diakses pada 1 Januari 2016 pukul 08.33

Adam, Mohammad dan Paramitha, Tasya. Viva News. ed. 3 Maret 2014. NATO: Intervensi Rusia ke Ukraina Ancam Perdamaian di Eropa. http://dunia.news.viva.co.id/news/read/485454-nato--intervensi-rusiake-ukraina-ancam-perdamaian-di-eropa diakses pada 14 April 2015 pukul 07.26 
Adzani, Fadli, Uni Eropa Perpanjang Sanksi Untuk Rusia. CNN Indonesia. 22 Juni 2015. http://www.cnnindonesia.com/internasional/20150622174807-13461675/uni-eropa-perpanjang-sanksi-untuk-rusia/ diakses pada 25 Januari 2016 pukul 07.25

Alfiansyah, Octab. Upaya Rusia Dalam Mencegah Rencana Ukraina Masuk. Keanggotaan Uni Eropa. ejournal Ilmu Hubungan Internasional. Volume 3. Nomor 2. Tahun 2015. http://ejournal.hi.fisip-unmul.ac.id/site/wpcontent/uploads/2015/05/825.-Octab-Alfiansyah-0902045071.pdf diakses pada 17 Januari 2016 pukul 18.32

AS dan Uni Eropa Sebut Referendum Crimea Ilegal. Kompas.com. 7 Maret 2014. http://tekno.kompas.com/read/2014/03/07/1004012/as.dan.uni.eropa. sebut.referendum.crimea.ilegal diakses pada 26 Januari 2016 pukul 10.29

Auliani, Palupi Annisa. Ukraina Punya Presiden Sementara. Kompas.com. Senin 24 Februari 2014.

http://internasional.kompas.com/read/2014/02/24/0352077/Ukraina. Punya.Presiden.Sementara diakses pada 20 Januari 2016 pukul 11.38

Azmi, Riza dan Hidayat Syarif. 2014. Ketahanan Energi: Konsep. Kebijakan dan Tantangan bagi Indonesia.

http://www.kemenkeu.go.id/sites/default/files/Energy\%20Security.pdf diakses pada 22 Juni 2015 pukul 18.20

BBC. 2014 (c). Why Is Ukraine In Turmoil. http:/ / www.bbc.co.uk/news/world-europe25182823 diakses pada 14 April 2015 pukul 07.30

BBC. Parlemen Ukraina Memecat Presiden. 23 Februari 2014 (a). http://www.bbc.com/indonesia/dunia/2014/02/140222_Ukraina_presi den_parlemen diakses pada 20 Januari 2015 pukul 09.32

BBC. Referendum Krimea Berlangsung Hari Ini. 16 Maret 2014 (b). http://www.bbc.com/indonesia/dunia/2014/03/140316_krimea_refere ndum diakses pada 20 Januari 2016 pukul 12.43

Belkin, Paul et.all. NATO: Response to the Crisis in Ukraine and Security Concerns in Central and Eastern Europe. $31 \quad$ Juli 2014. https://www.fas.org/sgp/crs/row/R43478.pdf diakses pada 24 Februari 2014 pukul 12.47 
De Britto, Johannes Sutanto. Uni Eropa dan NATO Bersatu Hadang Ancaman Rusia. $\begin{array}{lllll}\text { Jaring } & \text { News. } & 14 & \text { Mei }\end{array}$ http://www.jaringnews.com/internasional/uni-eropa/70285/uni-eropadan-nato-bersatu-hadang-ancaman-rusia diakses pada 30 Januari 2016 pukul 00.42

Dua wilayah Ukraina Siap Referendum Pemisahan Diri. Okezone.com. 11 Mei 2014 (a). http://news.okezone.com/read/2014/05/11/414/983293/dua-wilayahukraina-siap-referendum-pemisahan-diri diakses pada 25 Januari 2015 pukul 10.36

DW News. Pertempuran berkobar lagi di Ukraina Timur. 3 Juni 2014 (a). http://www.dw.com/id/pertempuran-berkobar-lagi-di-ukraina-timur/a17679401 diakses pada 25 Januari 2016 pukul 11.02

DW News. Sanksi Baru Terhadap Rusia Mulai Diterapkan. 12 September 2014 (b). http://www.dw.com/id/sanksi-baru-terhadap-rusia-mulai-diterapkan/a17917673 diakses pada 25 Januari 2016 pukul 07.35

Ekonomi Mengalami Stagnan, Rusia Dikeluarkan dari G8. Maret 2014. http://www.medanbisnisdaily.com/news/read/2014/03/26/86604/eko nomi-mengalami-stagnan-rusia-dikeluarkan-dari-g8/ diakses pada 24 Februari 2016 pukul 10.22

Ekonomi Rusia Sedang Kritis, AS dan Eropa Tidak Akan Kurangi Sanksinya. VibizNews.com. Desember 2014 (a). http://vibiznews.com/tag/sanksiekonomi/\# diakses pada 24 Januari 2016 pukul 09.48

Energy Security and Pipelines Politics in Europe.

http://pipelinesinternational.com/news/energy_security_and_pipeline_ politics_in_europe/053586/\# diakses pada 10 Maret 2016 pukul 14.10

EU Relations with Norway. http://eeas.europa.eu/norway/index_en.htm diakses pada 21 Maret 2016 pukul 10.34

European Commision. 2014. Stress Tests: Cooperation Key Coping Potential Gas Disruption. http://ec.europa.eu/energy/en/news/stress-tests-cooperation-keycoping-potential-gas-disruption diakses pada 25 Februari 2016 pukul 09.43 
European Commision. Energy Security Strategy. https://ec.europa.eu/energy/node/192

(b) diakses pada 3 Maret 2016 pukul 10.40

European Commision. Energy: Import and Secure Supplies. https://ec.europa.eu/energy/en/topics/imports-and-secure-supplies (a) diakses pada 25 Februari 2016 pukul 09.28

European Council on Foreign Relations. BBC News. 2009.

http://news.bbc.co.uk/2/hi/europe/7817043.stm diakses pada 09 Juni 2014 pukul 16.07

Fadly, Muhammad. Kebijakan Presiden Ukraina Viktor Yanukorych Menolak Menandatangani EU - Ukraine Association Agreement Dengan Uni Eropa Tabun 2013. jom FISIP. Volume 2. No.2. Oktober 2015. HI Universitas Riau. http://jom.unri.ac.id/index.php/JOMFSIP/article/download/7224/690 5 diakses pada 19 Januari 2016 pukul 15.47

Hasugian, Maria Rita. Referendum Crimea Diikuti 1,5 Juta Pemilib. Tempo.co. 2014. http://dunia.tempo.co/read/news/2014/03/16/117562670/referendu m-crimea-diikuti-1-5-juta-pemilih\# diakses pada 26 Januari 2016 pukul 10.14

Hatton, Daniel. Did The Orange Revolution Change Ukraine's Geopolitical Position Regarding Russia and The West?. University of Leeds. POLIS Jurnal. Vol. 3. Winter 2010. http://www.polis.leeds.ac.uk/assets/files/students/studentjournal/ug-summer-10/daniel-hatton-summer-10.pdf diakses pada 21 Januari 2016 pukul 22.15

IRIB Indonesia. Hasil Referendum Crimea: 97 Persen Ingin Bergabung dengan Rusia. 17 Maret 2014. http://indonesian.irib.ir/international/eropa/item/78059Hasil_Referendum_Crimea-

_97_Persen_Ingin_Bergabung_dengan_Rusia diakses pada 26 Januari 2016 pukul 10.40

Jatmika, Aningtias. NATO Siapkan 5 Pangkalan Tambahan di Eropa Timur. Tempo.co. dari kantor berita Rusia RIA Novosti, 2 September 2014. https://dunia.tempo.co/read/news/2014/09/02/117603892/natosiapkan-5-pangkalan-tambahan-di-eropa-timur diakses pada 31 Januari 2016 pukul 13.56 
Kerry: AStakbisa Abaikan Intervensi Rusia di Ukrania. 2015. http://www.voaindonesia.com/content/kerry-as-tak-bisa-abaikanintervensi-rusia-/2630542.html diakses pada 14 November 2015 pukul 08.00

Krisis Ukaraina-Russia. 2014. http://jakartagreater.com/krisis-ukraina-russia/ diakses pada Senin 20 Mei 2014 pukul 12.08

Litovkin, Dimitry. Sanksi Untuk Rusia, Siapa yang Lebih Rugi?. RBTH. 24 Maret 2014. http://indonesia.rbth.com/politics/2014/03/28/sanksi_militer_untuk_r usia_siapa_yang_lebih_rugi_23481 diakses pada 25 Januari 2016 pukul 10.45

Matsaberidze, David. Russia vs. EU/US Through Georgia and Ukraine. Connection: The Quarterly Journal. Volume XIV. Nomor 2. Spring 2015. http://connections-qj.org/system/files/14.2.06_matsaberidze_0.pdf diakses pada 2 Februari 2016 pukul 01.40

Muhaimin. Pakai Tank, Pasukan Separatis Pro-Rusia dan Pasukan Kiev Perang. Sindo News. 19 Juni 2014.

http:/ /international.sindonews.com/read/875070/41/pakai-tankseparatis-pro-rusia-dan-pasukan-kiev-perang-1403165043 diakses pada 25 Januari 2016 pukul 11.16

Mutiasari, Tia. Rusia Tawarkan Jadi Tuan Rumah Perundingan Gas EU-Ukraina. 2014. http://www.antaranews.com/berita/430888/Rusia-tawarkan-jadi-tuanrumah-perundingan-gas-eu-ukraina diakses pada 13 Januari 2015 pukul 22.17

NATO's with Celations Asial http://www.nato.int/cps/en/natolive/topics_107957.htm (b) diakses pada 25 April 2016 pukul 04.02

NATO-EU a Startegic Partnership. http://nato.int/cps/en/natohq/topics_49217.htm (c) diakses pada 29 Januari pukul 01.03

Nichol, Jim. Russian Political, Economic and Security Issues and U.S. Interest. Congressional $\begin{array}{lllll}\text { Research } & \text { Services. } & 31 & \text { Maret }\end{array}$ https://www.fas.org/sgp/crs/row/RL33407.pdf diakses pada 24 Februari 2016 pukul 10.12 
Nursalikah, Ani. Pertempuran berlangsung di Mariupol. Republika.com. 06 September 2014. http://www.republika.co.id/berita/koran/internasionalkoran/14/09/06/nbgyk2-pertempuran-berlangsung-di-mariupol diakses pada 25 Januari 2016 pukul 10.51

Peristiva Terkini di Ukraina. 2014. http://indonesia.mfa.gov.ua/id/presscenter/news/18237-potochna-situacija-v-ukrajini diakses pada 20 Januari 2014 pukul 11.24

Pranoto, M. Arif. 2014. Membaca Krisis Ukraina Dari Perspektif Geopolitik (3/habis). http://theglobalreview.com/content_detail.php?lang $=\mathrm{id} \& \mathrm{id}=14629 \&$ type $=99 \# . \mathrm{VqUNn}$ UA0bIV diakses pada 26 Januari 2016 pukul 11.09

Russia and Europe's Mutual Energy Dependence. April 2010. http://jia.sipa.columbia.edu/russia-and-europes-mutual-energydependence/ diakses pada 10 Maret 2016 pukul 14.15

Russia: Ukraine Crisis Destablizing Russia's Geopolitical Position. 2015. http://www.nids.mod.go.jp/english/publication/eastasian/pdf/2015/east-asian_e2015_06.pdf halaman 207 diakses pada 31 Januari 2016 pukul 23.07

Russia's Key Energy Statistics.

http://www.eia.gov/beta/international/country.cfm?iso=RUS diakses pada 20 Januari 2014 pukul 13.53

Sanjoyo, Anto. Rusia Bermain Api di Crimea. Ed. Minggu, 2 Maret 2014. Harian Kompas. http://internasional.kompas.com/read/2014/03/02/1001125/Rusia.Ber main.Api.di.Crimea diakses pada 14 April 2015 pukul 09.13

Selain IMF berikan Bailout, Ukraina Dapat Bantuan Tambahan Dari World Bank dan Uni Eropa. 2 Mei 2014 (b). http://vibiznews.com/tag/ukraina/ diakses pada 25 April 2016 pukul 02.03

Sinaga, Shinta. Kirim tentara ke Ukraina: Putin Niat Bentuk 'Reinkarnasi Uni Soviet'. 4 Maret 2014, http://news.liputan6.com/read/2018084/kirim-tentara-keukraina-putin-niat-bentuk-reinkarnasi-uni-soviet diakses pada 3 Maret 2016 pukul 11.04 
Suplier Country. https://ec.europa.eu/energy/en/topics/imports-and-securesupplies/supplier-countries (c) diakses pada 25 Februari 2016 pukul 09.17

Suryana, Asep. 2007. Tahap-tahap Penelitian Kualitatif: Mata Kuliah Analisis Data Kualitatif. Fakultas Ilmu Pendidikan. Universitas Pendidikan Indonesia. http://file.upi.edu/Direktori/FIP/JUR._ADMINISTRASI_PENDIDI KAN/197203211999031-

ASEP_SURYANA/Copy_(4)_of_LANGKAH_PENELITIAN_KUAL

ITATIF.pdf diakses pada 25 April 2016 pukul 09.00

Turkmenistan.https://www.eia.gov/beta/international/country.cfm?iso=TKM diakses pada 31 Januari 2016 pukul 02.45

U.S. Energy Information Administration based on reporting countries import statistics. Global Trade Information Service. https://www.eia.gov/beta/international/analysis.cfm?iso=RUS diakses pada 23 Januari 2016 pukul 10.53

UE-Asia Tengah Lakukan Kerja Sama Menyelurub dengan Bidang Energi sebagai Perintis. CRI Online. $\quad 11 \quad$ April 2008. http://indonesian.cri.cn/1/2008/04/11/1@80191.htm diakses pada 31 Januari 2016 pukul 02.53

Uni Eropa Perluas Sanksi Untuk Rusia. BBC News. 30 Juli 2014 (d). http://www.bbc.com/indonesia/dunia/2014/07/140729_rusia_uni_ero pa_sanksi diakses pada 25 Januari 2016 pukul 07.31

Usai Referendum Dua Wilayah Ukraina Pilih Pisah. Okezone.com. 12 Mei 2014 (b). http://news.okezone.com/read/2014/05/12/414/983544/usaireferendum-dua-wilayah-ukraina-pilih-pisah diakses pada 25 Januari 2016 pukul 11.35

VOA New. Ukraina akan Ajukan Permohonan Jadi Anggota Uni Eropa. 2014 (b). http:/ /www.voaindonesia.com/content/ukraina-akan-masuk-unieropa/2462358.html diakses pada 21 Maret 2016 pukul 07.09

VOA news. Poroshenko Dilantik Menjadi Presiden Ukraina. 07 Juni 2014 (a). http://www.voaindonesia.com/content/poroshenko-dilantik-sebagaipresiden-Ukraina-/1931785.html diakses pada 19 Januari 2016 pukul 22.15 
Wahroel, Steven. Ukraine: Current Issues and U.S. Policy. 24 Maret 2014. Congressional Research Service. http://www.refworld.org/pdfid/533d47eb4.pdf diakses pada 31 Januari 2016 pukul 23.15.

What is NATO. http://www.nato.int/nato-welcome/index.html (e) diakses pada 30 Januari pukul 01.33

Wibisono, Kunto. Parlemen Eropa Setujui Bantuan Dana Sebesar 1,8 Miliar Euro ke Ukraina. 26 Maret 2016.

http://www.antaranews.com/berita/487412/parlemen-eropa-setujuibantuan-dana-18-miliar-euro-ke-ukraina diakses pada 25 April 2016 pukul 09.01

Wisnu, Dinna. SindoNews. 2014. Krisis Semenanjung Crimea. http://nasional.sindonews.com/read/841394/18/krisis-semenanjungcrimea-1394002513/ diakses pada 14 April 2014 pukul 07.44. 